\section{ИНФОРМАЦИОННАЯ ЕМКОСТЬ} ФАСЕТОЧНЫХ

\section{ОПТИКО-ЭЛЕКТРОННЫХ}

\section{СИСТЕМ}

\author{
B.A.Соломатин,vsolomatin@mail.ru, \\ Московский государственный университет гео- \\ дезии и картографии, Москва, Россия
}

Современные микроминиатюрные цифровые фото- и видеокамеры строятся по принципам, характерным для фасеточного глаза насекомых. Стремление увеличить число и размер пикселов используемых фотоматриц имеют, очевидно, технологические ограничения, определяющие во многом информационную емкость системы. Вместе с тем существуют и теоретические ограничения информационной емкости. Прежде всего, это дифракционные ограничения, определяющие предел пространственного разрешения для микрооптических систем. Кроме того, это энергетические ограничения, связанные с отношением сигнал / шум во время экспозиции. В статье рассмотрены эти ограничивающие информационную емкость системы факторы и получены аналитические зависимости, позволяющие определить рациональное сочетание параметров фасеточной оптико-электронной системы и рассчитать ее информационную емкость с учетом отмеченных ограничений.

\section{ВВЕДЕНИЕ}

В фасеточных оптико-электронных системах в определенной мере реализуются принципы построения глаза насекомых, ракообразных и некоторых других беспозвоночных. Оптиче скую модель фасеточного глаза можно предста вить как совокупность сопряженных микролинз и фоторецепторов, воспринимающих поток излу чения определенного направления (рис. 1). Такие маленькие "глазки", называемые омматидиями, направлены во все стороны и могут охватывать огромное угловое поле вплоть до полной сферы. Число омматидий может составлять десятки тысяч, у стрекозы, например, их 30000 . Такие достоинства фасеточного глаза, как большое угловое поле, миниатюрность, большая глубина изображаемого

\section{INFORMATION CAPACITY OF FACET OPTOELECTRONIC} SYSTEMS

\author{
V.A.Solomatin,vsolomatin@mail.ru, \\ Moscow State University of Geodesy and Cartography, \\ Moscow, Russia
}

Modern microminiature digital photo and video cameras are built according to the principles typical for the facet eye of insects. The desire to increase the number and size of the pixels used by the photomatrix obviously has technological limitations that determine the information capacity of the system. At the same time, there are theoretical limitations of information capacity. First of all, these are diffraction limitations that determine the limit of spatial resolution for micro-optical systems. In addition, these are energy limitations related to the signal-to-noise ratio during exposure. In the article these factors limiting the information capacity of the system are considered and formulas are obtained that allow to determine the rational combination of parameters of the facet optoelectronic system and calculate its information capacity taking into account the noted limitations. The parameters of known foreign developments are close to those calculated by the above formulas.

\section{INTRODUCTION}

In facet optoelectronic systems, to a certain extent, the principles of constructing the eye of insects, crustaceans and some other invertebrates are implemented. The optical model of the facet eye can be represented as a set of conjugated microlenses and photoreceptors that perceive the radiation flux of a certain direction (Fig. 1). Such small "eyes", called ommatidia, are directed in all directions and can cover a huge angular field up to the full sphere. The number of ommatidia can be tens of thousands, e. g. , a dragonfly has 30,000 of them. Such advantages of the facet eye as a large angular field, miniature size, large depth of the imaged space, invariably attract the developers of optoelectronic systems of circular viewing of space, video surveillance, control, technical vision of robots, pattern recognition, photo and video. However, at small values of the focal length of microlenses, the spatial resolution, determined by the angle $\Delta \alpha$, is obviously low. 
пространства неизменно привлекают разработчиков оптико-электронных систем кругового обзора пространства, видеонаблюдения, контроля, технического зрения роботов, распознавания образов, фото- и видеосъемки. Однако при малых значениях фокусного расстояния микролинз, очевидно, пространственное разрешение, определяемое углом $\Delta \alpha$, оказывается невысоким.

Оптико-электронные системы различного назначения не копируют устройство фасеточного глаза, а реализуют отдельные принципы, заложенные в его строении. Так, например, системы кругового обзора могут содержать множество каналов, расположенных по окружности, обеспечивая тем самых охват 360-градусного поля. Обзор фасеточных оптико-электронных систем различного типа содержится в работах [1,2].

Наиболее близкими к фасеточному глазу по принципу построения являются системы, в которых используются микрообъективы, создающие изображение на фотоматрице - микрооптические фасеточные системы. Именно такие системы

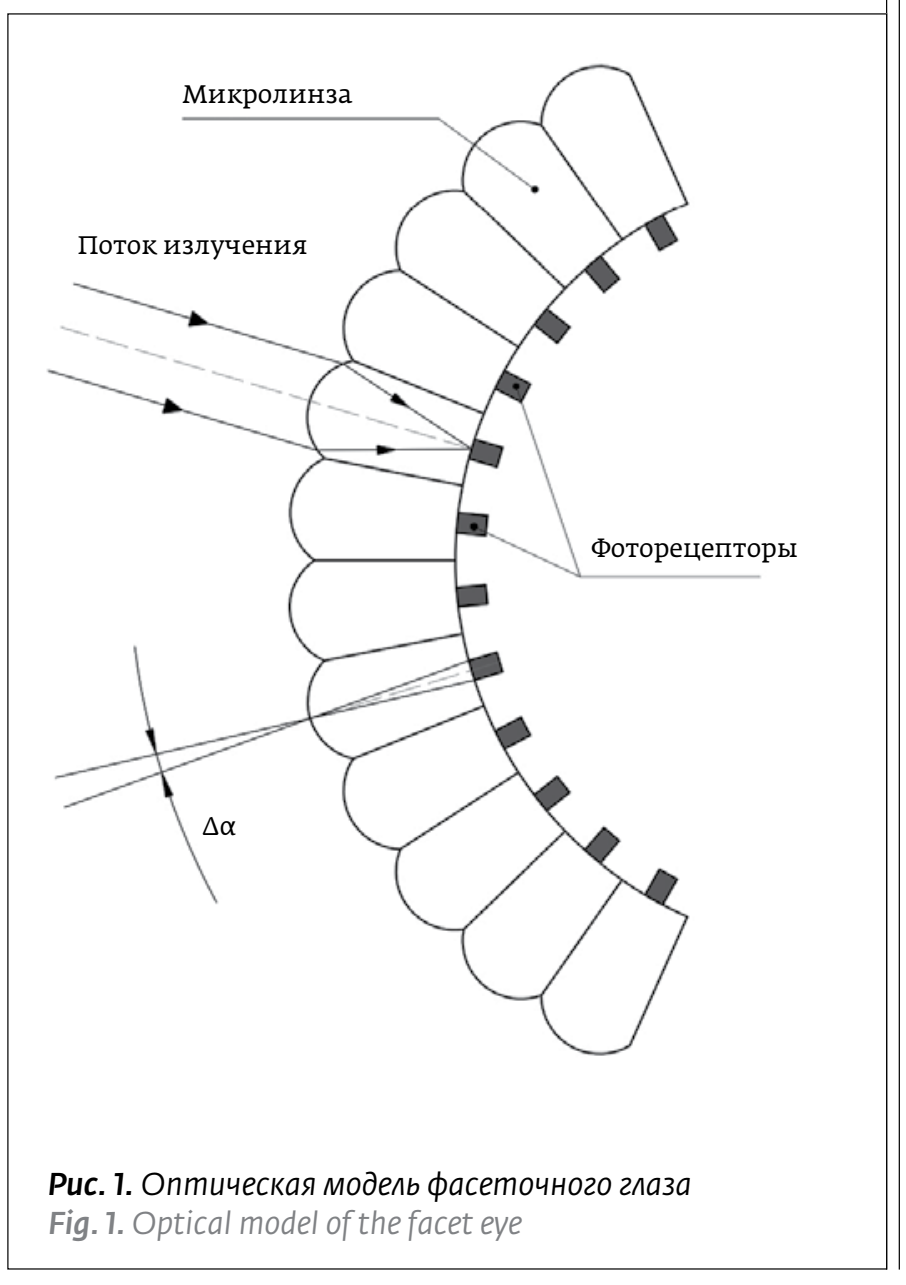

Optoelectronic systems for various purposes do not copy the arrangement of the facet eye, but implement certain principles inherent in its structure. Thus, all-around vision system can contain multiple channels located around the circumference, providing the most coverage of a 360-degree field. A review of facet optoelectronic systems of various types is given in $[1,2]$.

According to the principle of construction, the systems that use microlenses that create an image on a photomatrix, micro-optical facet systems, are the closest to the facet eye. Such systems provide minimization of dimensions and weight of the device.

The information capacity of micro-optical facet systems has certain limits related not only to the number of elements of a photomatrix, but also to fundamental physical limitations: diffraction and the signal-to-noise ratio (energy limitations).

The purpose of the article is to find the relationship between the parameters of the optical system, the parameters of the photomatrix and the conditions of illumination, allowing to calculate the information capacity of the facet optoelectronic system and to determine the rationality of the combination of its basic elements.

\section{DIFFRACTION LIMITATIONS}

In recent years, attempts to technically implement facet vision have been made in a number of research laboratories in the USA, Japan, Switzerland, and Germany [3-5]. They are aimed at solving an important problem of increasing spatial resolution due to the use of not a single element radiation detector (photoreceptor), but a photomatrix, and the choice of mutual placement of microlenses and photomatrix. Various technical and technological solutions are proposed, but from the point of view of determining information capacity, the facet vision system can be represented as a set of units (facets) containing microlenses, each of which is associated with a photomatrix. The image created by the microlens covers the area of the photomatrix with a certain number of elements (pixels). Facets can be located on the dome surface, due to which a wide angular field of the system is achieved [6]. The technological process developed at the Fraunhofer Institute of Optics and Precision Engineering in Jena (Germany) made it possible to manufacture a flat chamber with a thickness of only $2 \mathrm{~mm}$. A conceptual prototype of such a device is known as facetVISION [7].

Let's assume that the microlens has a light diameter $D$ (Fig. 2). The minimum image area required to overlap 
обеспечивают минимизацию габаритов и массы устройства.

Информационная емкость микрооптических фасеточных систем имеет определенные пределы, связанные не только с числом элементов фотоматрицы, но и с принципиальными физическими ограничениями - дифракцией и отношением сигнал / шум (энергетические ограничения).

Цель статьи - найти взаимосвязь между параметрами оптической системы, параметрами фотоматрицы и условиями освещенности, позволяющую рассчитать информационную емкость фасеточной оптико-электронной системы и определить рациональность сочетания ее основных элементов.

\section{1. ДИФРАКЦИОННЫЕ ОГРАНИЧЕНИЯ}

В последние годы в ряде исследовательских лабораторий США, Японии, Швейцарии, Германии предприняты попытки технической реализации фасеточного зрения [3-5]. Они направлены на решение важной проблемы увеличения пространственного разрешения за счет использования не одноэлементного приемника излучения (фоторецептора), а фотоматрицы и выбора взаимного размещения микролинз и фотоматрицы. Предлагаются различные технические и технологические решения, но, с точки зрения определения информационной емкости, систему фасеточного зрения можно представить как совокупность блоков (фасеток), содержащих микролинзы, каждая из которых сопряжена с фотоматрицей. Изображение, создаваемое микролинзой, охватывает участок фотоматрицы с определенным числом элементов (пикселов). Фасетки могут располагаться на купольной поверхности, за счет чего достигается широкое угловое поле системы [6]. Технологический процесс, разработанный в Институте оптики и точной механики, входящем в состав Института Фраунгофера (Иена, Германия), сделал возможным изготовление плоской камеры толщиной всего 2 мм. Концептуальный прототип такого устройства известен под названием facetVISION [7].

Допустим, что микролинза имеет световой диаметр D (рис. 2). Минимальная площадь изображения, необходимая для перекрытия поля обзора одной микролинзы при расположении микролинз по строкам и столбцам с равными интервалами, равна $D^{2}$. С учетом необходимого для сшивки изображения перекрытия угловых полей микролинз требуемая площадь изображения должна быть больше, однако перекрываемые площади не входят в информационную емкость результирующего

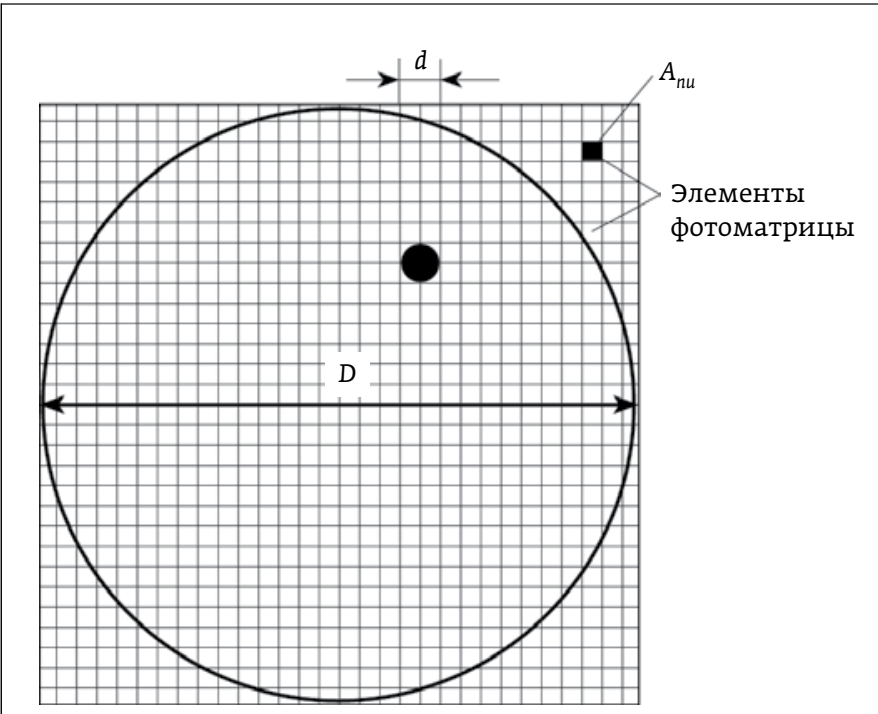

Puc. 2. Геометрические параметры микрооптической системы

Fig. 2. Geometric parameters of the micro-optic system

the field of view of one microlens with the location of microlenses in rows and columns at equal intervals is equal to $D^{2}$. Taking into account the overlap of the angular fields of microlenses required for stitching an image, the required image area should be larger, however, the overlapped areas are not included in the information capacity of the resulting ("crosslinked") image. Under diffraction limitations, the diameter of the scattering circle (Erie circle) is equal to

$$
d=\frac{2,44 \cdot \lambda}{D} f^{\prime},
$$

where $\lambda$ is the radiation wavelength, $f^{\prime}$ is focal length of the microlens.

We assume that the area of a pixel determined by diffraction is equal to the area of a square with side $d$, i.e.,

$$
d^{2}=\left(\frac{2,44 \cdot \lambda}{D} f^{\prime}\right)^{2}
$$

Then the number of pixels in the angular field of the microlens will be equal to

$$
N_{1}=\left(\frac{D}{d}\right)^{2}=0,17\left(\frac{D}{f^{\prime}}\right)^{2}\left(\frac{D}{\lambda}\right)^{2},
$$

where $\frac{D}{f^{\prime}}$ is the relative aperture of the microlens.

It is known that the image can be restored without distortion, if the number of samples per pixel is at least two [8], i.e., the number of photomatrix elements in the angular field of a microlens should 
(“сшитого") изображения. При дифракционных ограничениях диаметр кружка рассеяния (кружка Эри) равен

$$
d=\frac{2,44 \cdot \lambda}{D} f^{\prime},
$$

где $\lambda$ - длина волны излучения, $f^{\prime}-$ фокусное расстояние микролинзы.

Будем считать, что площадь пиксела, определяемого дифракцией, равна площади квадрата со стороной $d$, т.е.

$$
d^{2}=\left(\frac{2,44 \cdot \lambda}{D} f^{\prime}\right)^{2} .
$$

Тогда число пикселов в угловом поле микрообъектива будет равно $N_{1}=\left(\frac{D}{d}\right)^{2}=0,17\left(\frac{D}{f^{\prime}}\right)^{2}\left(\frac{D}{\lambda}\right)^{2}$, где $\frac{D}{f^{\prime}}-$ относительное отверстие микролинзы.

Известно, что изображение может быть восстановлено без искажений, если число выборок на пиксел составляет не менее двух [8], то есть число элементов фотоматрицы в угловом поле микрообъектива должно быть $2 \mathrm{~N}_{1}$, а если фасеточная система содержит n микрообъективов, то общее число элементов фотоматрицы должно составлять

$$
\mathrm{N}_{\Sigma}=0,34 \mathrm{n}\left(\frac{\mathrm{D}}{f^{\prime}}\right)^{2}\left(\frac{D}{\lambda}\right)^{2} .
$$

\section{2. ЭНЕРГЕТИЧЕСКИЕ ОГРАНИЧЕНИЯ}

Если на элементе фотоматрицы возможно выделение $m$ градаций яркости и значения яркости равновероятны, то, по формуле Хартли, информационная емкость поля яркости определяется через статистическую энтропию как

$$
\mathrm{H}=\mathrm{N}_{\Sigma} \log _{2}(m+1),
$$

или

$$
\mathrm{H}=0,34 n\left(\frac{D}{f^{\prime}}\right)^{2}\left(\frac{D}{\lambda}\right)^{2} \log _{2}(m+1) .
$$

Число градаций яркости в зависимости от отношения сигнал / шум $\mu$ примем равным

$$
m=k \mu,
$$

где $k$ - коэффициент, численно равный минимально допустимому отношению сигнал/шум. Отношение сигнал/шум записывается с использованием либо линейной, либо логарифмической шкалы. be $2 N_{1}$, and if the facet system contains $n$ microlenses, then the total number of photomatrix elements should be make up

$$
N_{\Sigma}=0,34 n\left(\frac{D}{f^{\prime}}\right)^{2}\left(\frac{D}{\lambda}\right)^{2}
$$

\section{ENERGY LIMITATIONS}

If it is possible to select $m$ gradations of brightness on the photomatrix element, and the brightness values are equally probable, then, using the Hartley formula, the information capacity of the brightness field is determined through statistical entropy as

$$
H=N_{\Sigma} \log _{2}(m+1),
$$

or

$$
H=0,34 n\left(\frac{D}{f^{\prime}}\right)^{2}\left(\frac{D}{\lambda}\right)^{2} \log _{2}(m+1) .
$$

The number of gradations of brightness, depending on the signal-to-noise ratio $\mu$, is equal to

$$
m=k \mu,
$$

where $k$ is a coefficient numerically equal to the minimum acceptable signal-to-noise ratio. The signalto-noise ratio is recorded using either a linear or a logarithmic scale.

The signal-to-noise ratio $(\mathrm{S} / \mathrm{N})$, measured in decibels, is defined as

$$
S / N=20 \lg \left(\frac{u_{c}}{\sqrt{\bar{u}_{u}^{2}}}\right),
$$

or

$$
\mu=10^{\frac{S / N}{20}},
$$

where $u_{c}$ is the signal level, $\sqrt{\bar{u}_{u}^{2}}$ is the r.m.s. value of the noise. In accordance with the expert assessment of image quality in television, recommended by the International Advisory Committee on Radio Engineering, satisfactory image quality can be obtained with a signal-to-noise ratio $\mathrm{S} / \mathrm{N}$ of at least $30 \mathrm{~dB}(\mu=32)$.

The signal and noise levels and the signal-to-noise ratio can be expressed in terms of the corresponding numbers of signal $n_{c}$ and noise $n_{u}$ electrons:

$$
\mu=\frac{n_{c}}{n_{u}}=\frac{n_{c}}{\sqrt{n_{\text {внш }}^{2}+n_{\text {фш }}^{2}}},
$$

where $n_{\text {внш }}$ is the number of internal noise electrons, $n_{\phi u}$ is the number of external noise electrons. External noises (photon noise) are the result of a discrete nature 
Отношением сигнал/шум (S/N), измеряемое в децибелах, определяется как

$$
S / N=20 \lg \left(\frac{u_{c}}{\sqrt{\bar{u}_{u}^{2}}}\right)
$$

или

$$
\mu=10^{\frac{S / N}{20}}, \text { крат, }
$$

где $u_{c}$ - уровень сигнала, $\sqrt{\bar{u}_{u}^{2}}$ - среднеквадратическое значение шума. В соответствии с экспертной оценкой качества изображения в телевидении, рекомендованной Международным консультативным комитетом по радиотехнике, удовлетворительное качество изображения может быть получено при отношении сигнал/шум S/N не менее 30 дБ $(\mu=32)$.

Уровни сигнала и шума и отношение сигнал/шум можно выразить через соответствующие числа сигнальных $n_{c}$ и шумовых $n_{u}$ электронов:

$$
\mu=\frac{n_{c}}{n_{u}}=\frac{n_{c}}{\sqrt{n_{\text {вн }{ }_{u}^{2}+n_{\phi \omega}^{2}}}},
$$

где $n_{\text {внш }}$ - число внутренних шумовых электронов, $n_{\phi ш}$ - число внешних шумовых электронов. Внешние шумы (фотонный шум) являются следствием дискретной природы и подчиняются закону Пуассона (статистике). Число шумовых электронов также следует этой статистике, и, согласно ей, фотонный шум равен квадратному корню из числа сигнальных электронов, то есть $n_{\phi ш}=\sqrt{n_{c}}$. Таким образом, при значительных отношениях сигнал / шум, когда $n_{\phi ш}^{2}>>n_{\text {вн }}^{2}$, отношение сигнал / шум будет равно корню квадратному из числа сигнальных фотонов:

$$
\mu=\sqrt{n_{c}}=n_{\phi \mu} .
$$

Число сигнальных электронов за цикл накопления на элементе фотоматрицы на длине волны $\lambda$, определяется как

$$
n_{c \lambda}=\frac{E_{\lambda} A_{n u} t_{H}}{W_{\lambda}} \eta_{\lambda}
$$

где $E_{\lambda}$ - спектральная облученность элемента фотоматрицы (здесь и далее используются энергетические величины, взятые в узком спектральном диапазоне $\Delta \lambda$, при этом $E_{\lambda}=E_{e \lambda} \Delta \lambda, E_{e \lambda}-$ спектральная плотность энергетической облученности), $A_{\text {nи }}$ - площадь пиксела, $t_{н}$ - время накопления, $W_{\lambda}=h v=\frac{h c}{\lambda}-$ энергия фотона на длине волны $\lambda$, and follow the Poisson law (statistics). The number of noise electrons also follows this statistics, and according to it, the photon noise is equal to the square root of the number of signal electrons, i. e. $n_{\phi m}=\sqrt{n_{c}}$. Thus, with significant signal-to-noise ratios, when $n_{\phi \omega}^{2}>>n_{B н m}^{2}$, the signal-to-noise ratio will be equal to the square root of the number of signal photons:

$$
\mu=\sqrt{n_{c}}=n_{\phi u} .
$$

The number of signal electrons per accumulation cycle on the photomatrix element at wavelength $\lambda$, is defined as

$$
n_{c \lambda}=\frac{E_{\lambda} A_{n u} t_{H}}{W_{\lambda}} \eta_{\lambda}
$$

where $E_{\lambda}$ is the spectral irradiance of the photomatrix element (hereinafter - the energy values taken in the narrow spectral range $\Delta \lambda$ are used, while $E_{\lambda}=E_{e \lambda} \Delta \lambda, E_{e \lambda}$ is the spectral density of energy irradiance, $A_{n u}$ is the pixel area, $t_{H}$ is accumulation time, $W_{\lambda}=h v=\frac{h c}{\lambda}$ is the photon energy at the wavelength $\lambda, \eta_{\lambda}$ is the quantum yield, $h=6,626 \cdot 10^{-34} \mathrm{~J} \cdot \mathrm{s}$ is Planck's constant.

It is easy to show that the spectral irradiance of the photomatrix element is determined by the relation:

$$
E_{\lambda}=\frac{E_{06 \lambda} r_{\lambda} \tau_{0 \lambda} \tau_{a \lambda}}{4}\left(\frac{D}{f^{\prime}}\right)^{2},
$$

where $E_{0 б \lambda}$ is the spectral irradiance of the object, $r_{\lambda}$ is the spectral reflectance ratio of the object, $\tau_{0 \lambda}$ is the spectral transmittance of the optical system, $\tau_{a \lambda}$ is the spectral transmittance of the atmosphere, $\frac{D}{f^{\prime}}$ is the relative aperture of the objective (microlens). From relations (4), (5) and (6), taking into account the fact that the area of the photomatrix element $A_{n u}$ should be half as much as $d^{2}$, we obtain:

$$
\mu=1,22 \lambda \cdot \sqrt{\frac{E_{o b \lambda} r_{\lambda} \tau_{0 \lambda} \tau_{a \lambda}}{W_{\lambda}} t_{H} \eta_{\lambda}} .
$$

Then from (2), (3) and (7) we obtain the formula determining the information capacity of the facet optoelectronic system, in the following form:

$$
H=0,34 n\left(\frac{D}{f^{\prime}}\right)^{2}\left(\frac{D}{\lambda}\right)^{2} \log _{2}\left(1,22 k \lambda \sqrt{\frac{E_{o b \lambda} r_{\lambda} \tau_{o \lambda} \tau_{a \lambda}}{W_{\lambda}} t_{H} \eta_{\lambda}}+1\right)
$$


$\eta_{\lambda}$ - квантовый выход, $h=6,626 \cdot 10^{-34}$ Дж $\cdot$ - - постоянная Планка.

Легко показать, что спектральная облученность элемента фотоматрицы определяется соотношением:

$$
E_{\lambda}=\frac{E_{06 \lambda} r_{\lambda} \tau_{0 \lambda} \tau_{a \lambda}}{4}\left(\frac{D}{f^{\prime}}\right)^{2},
$$

где $E_{0 б \lambda}$ - спектральная облученность объекта, $r_{\lambda}-$ спектральный коэффициент отражения объекта, $\tau_{0 \lambda}$ - спектральное пропускание оптической системы, $\tau_{a \lambda}$ - спектральное пропускание атмосферы, $\frac{D}{f^{\prime}}$ - относительное отверстие объектива (микролинзы). Из соотношений (4), (5) и (6) с учетом того, что площадь элемента фотоматрицы $A_{\text {пи }}$ должна быть вдвое меньше $d^{2}$, получим:

$$
\mu=1,22 \lambda \cdot \sqrt{\frac{E_{o b \lambda} r_{\lambda} \tau_{0 \lambda} \tau_{a \lambda}}{W_{\lambda}} t_{H} \eta_{\lambda}} .
$$

Тогда из (2), (3) и (7) получим формулу, определяющую информационная емкость фасеточ-

\section{ANALYSIS AND CONCLUSIONS}

The analysis of the relations obtained shows that increasing the number of photomatrix elements to enhance the information capacity of the system is advisable to a certain limit. A rational number of elements, as it follows from formula (1), is determined by the parameters of the microlens and the number of microlenses, which in turn depends on technological factors. On the other hand, for a given number of photomatrix elements, it is possible to calculate the required number of microlenses in the facet system. So, e.g., when using a 10-megapixel matrix, with relative aperture of the microlens $\frac{D}{f^{\prime}}=\frac{1}{2}$, with the wavelength $\lambda=0.5 \mu \mathrm{m}$, and with the diameter of the microlens $\mathrm{D}=0.5 \mathrm{~mm}, 118$ microlenses are enough. As $D$ decreases, the required number of microlenses increases dramatically.

The information capacity of the system significantly depends on the energy relations in accordance with (8). Knowing the object irradiance $E_{06 \lambda}$ and other parameters included in (7) and (8), one can calculate the signal-to-noise ratio $\mu$ and the contribution of the logarithmic multiplier to 
ной оптико-электронной системы, в следующем виде:

$$
H=0,34 n\left(\frac{D}{f^{\prime}}\right)^{2}\left(\frac{D}{\lambda}\right)^{2} \log _{2}\left(1,22 k \lambda \sqrt{\frac{E_{o b \lambda} r_{\lambda} \tau_{o \lambda} \tau_{a \lambda}}{W_{\lambda}} t_{H} \eta_{\lambda}}+1\right)
$$

\section{3. АНАЛИЗ И ВЫВОДЫ}

Анализ полученных соотношений показывает, что увеличение числа элементов фотоматрицы для повышения информационной емкости системы целесообразно до определенного предела. Рациональное число элементов, как это следует из формулы (1), определяется параметрами микролинзы и числом микролинз, что, в свою очередь, зависит от технологических факторов. С другой стороны, при заданном числе элементов фотоматрицы можно рассчитать необходимое число микролинз в фасеточной системе. Так, к примеру, при использовании 10-мегапикселной матрицы, относительном отверстии микролинзы $\frac{D}{f^{\prime}}=\frac{1}{2}$, длине волны $\lambda=0,5$ мкм и диаметре микролинзы $\mathrm{D}=0,5$ мм достаточно 118 микролинз. При уменьшении $D$ требуемое число микролинз резко возрастает.

Информационная емкость системы существенно зависит и от энергетических соотношений в соответствии с (8). Зная облученность объекта съемки $\mathrm{E}_{\text {обл }}$ и другие параметры, входящие в (7) и (8), можно рассчитать отношение сигнал / шум $\mu$ и вклад логарифмического множителя в информационную емкость фасеточной оптико-электронной системы. С другой стороны, определив требуемое значение $\mu$ по критериям качества изображения, можно найти необходимый уровень освещенности объекта съемки. Если положить в формуле (5) число электронов $n_{\lambda}$ равным шумовому числу $n_{\lambda m}$, то соответствующая облученность пиксела будет равна пороговой величине:

$$
E_{n \lambda}=\frac{W_{\lambda} n_{\lambda \mu}}{A_{n u} t_{H} \eta_{\lambda}}
$$

Полагая $E_{\text {обл}}=E_{n \lambda}$, получим с учетом соотношения (6) значение пороговой облученности объекта, при которой сигнал пиксела равен шуму:

$$
E_{n \lambda}^{o \sigma}=\frac{4 W_{\lambda} n_{\lambda \mu}}{A_{n u} t_{h} \eta_{\lambda} r_{\lambda} \tau_{0 \lambda} \tau_{a \lambda}\left(\frac{D}{f^{\prime}}\right)^{2}}=\frac{4 E_{n \lambda}}{r_{\lambda} \tau_{0 \lambda} \tau_{a \lambda}\left(\frac{D}{f^{\prime}}\right)^{2}} .
$$

the information capacity of the facet optoelectronic system. On the other hand, by determining the required value $\mu$ by the criteria of image quality, one can find the necessary level of illumination of the subject. If in the formula (5) we put the number of electrons $n_{\lambda}$ equal to the noise number $n_{\lambda m}$, then the corresponding irradiance of the pixel will be equal to the threshold value

$$
E_{n \lambda}=\frac{W_{\lambda} n_{\lambda \mu}}{A_{n u} t_{H} \eta_{\lambda}} .
$$

Assuming $E_{0 б \lambda}=E_{n \lambda}$, we obtain, taking into account relation (6), the value of the threshold irradiance of the object, at which the pixel signal is equal to noise:

$$
E_{n \lambda}^{o \sigma}=\frac{4 W_{\lambda} n_{\lambda \mu}}{A_{n u} t_{h} \eta_{\lambda} r_{\lambda} \tau_{0 \lambda} \tau_{a \lambda}\left(\frac{D}{f^{\prime}}\right)^{2}}=\frac{4 E_{n \lambda}}{r_{\lambda} \tau_{0 \lambda} \tau_{a \lambda}\left(\frac{D}{f^{\prime}}\right)^{2}} .
$$

Then the maximum spectral irradiance of the object in the range of linearity of the energy characteristic is equal to:

$$
E_{\lambda \max }^{o \sigma}=\frac{4 W_{\lambda} n_{\lambda c}}{A_{n u} t_{H} \eta_{\lambda} r_{\lambda} \tau_{0 \lambda} \tau_{a \lambda}\left(\frac{D}{f^{\prime}}\right)^{2}}=E_{n \lambda}^{o 6} \mu
$$

For typical values: signal-to-noise ratio $S / \mathrm{N} 40 \mathrm{~dB}$ $(\mu=100), \lambda=0.5 \mu \mathrm{m}, A_{n u}=25 \cdot 10^{-12}$ (photomatrix element size $5 \mu \mathrm{m}), t_{\mathrm{H}}=0,02 \mathrm{c}, \eta_{\lambda}=0,4, r_{\lambda}=0,6, \tau_{o \lambda}=0,8, \tau_{a \lambda}=1$, $\frac{D}{f^{\prime}}=0,5$ we obtain $E_{n \lambda}=1,98 \mathrm{~W} / \mathrm{m}^{2}, E_{n \lambda}^{06}=66 \cdot 10^{-4} \mathrm{~W} / \mathrm{m}^{2}$ which in terms of light units corresponds to object illumination 270 lux.

Thus, the goal set in the article seems to have been achieved. The obtained formulas determine the relationship between the parameters of the optical system, the parameters of the photomatrix and the illumination conditions, allowing us to calculate the information capacity of the facet optoelectronic system and determine the rationality of the combination of its main elements: the number of photomatrix elements, its format, element size, microlens number, diameter and relative aperture microlenses. The calculation using the given formulas shows that some of the parameters sparingly published by the developers of the facet systems, primarily, the number of microlenses and the parameters of photomatrices, correspond to the calculated values. 
Тогда максимальная спектральная облученность объекта в диапазоне линейности энергетической характеристики равна:

$$
E_{\lambda \max }^{o \sigma}=\frac{4 W_{\lambda} n_{\lambda c}}{A_{n u} t_{H} \eta_{\lambda} r_{\lambda} \tau_{0 \lambda} \tau_{a \lambda}\left(\frac{D}{f^{\prime}}\right)^{2}}=E_{n \lambda}^{06} \mu .
$$

Для достаточно типовых значений: отношении сигнал/шум S/N 40 дБ $(\mu=100), \lambda=0,5$ мкм, $\mathrm{A}_{\text {nu }}=25 \cdot 10^{-12} \mathrm{M}^{2}$ (размер элемента фотоматрицы 5 MKM), $t_{\mathrm{H}}=0,02 \mathrm{c}, \eta_{\lambda}=0,4, r_{\lambda}=0,6, \tau_{0 \lambda}=0,8, \tau_{a \lambda}=1$, $\frac{D}{f^{\prime}}=0,5$ получим $E_{n \lambda}=1,98 \mathrm{BT} / \mathrm{M}^{2}, E_{n \lambda}^{06}=66 \cdot 10^{-4} \mathrm{BT} / \mathrm{M}^{2}$, $E_{\lambda \max }^{o 6}=66 \cdot 10^{-2} \mathrm{BT} / \mathrm{M}^{2}$, что в пересчете к световым единицам соответствует освещенности объекта 270 лк.

Таким образом, поставленная в статье цель представляется достигнутой. Получены формулы, определяющие взаимосвязь между параметрами оптической системы, параметрами фотоматрицы и условиями освещенности, позволяющие рассчитать информационную емкость фасеточной оптико-электронной системы и определить рациональность сочетания ее основных элементов - числа элементов фотоматрицы, ее формата, размера элемента, числа микролинз, диаметра и относительного отверстия микролинзы. Расчет по приведенным формулам показывает, что некоторые скупо публикуемые разработчиками фасеточных систем параметры, прежде всего число микролинз и параметры фотоматриц, соответствуют расчетным значениям.

\section{СПИСОК ЛИТЕРАТУРЫ}

1. Соломатин В.А. Фасеточное зрение: перспективы в оптико-электронных системах. Фотоника. 2009; 1: 22-26.

Solomatin V.A. Fasetochnoe zrenie: perspektivy v optiko-ehlektronnyh sistemah. Fotonika. 2009; 1: 22-26

2. Соломатин В.А., Мартынов Д. В. Фасеточные оптико-электронные системы с фокальными матрицами. Приборы и системы. Управление, контроль, диагностика. 2015; 7: 50-55.

Solomatin V.A., Martynov D. V. Fasetochnye optiko-ehlektronnye sistemys fokal'nymi matricami. Pribory i sistemy. Upravlenie, kontrol', diagnostika. 2015; 7 : 50-55.

3. http://blog.smu.edu/research/2009/03/10/hi-tech-lens-sharpens-militarysurveillance/\#more

4. URL: http://actu.epfl.ch/news/a-360-camera-that-sees-in-3d/

5. URL: http://jonaspfeil.de/ballcamera

6. URL: http://savepearlharbor.com/?p=188620.

7. URL: http://facetvision.de Ultra Thin Imaging Solutions - facetvision

8. Цыцулин А. К., Адамов Д. Ю., Манцветов А.А., Зубакин И.А. Твердотепьные телекамеры: накоппение качества информации. СПб.: - СПбГЭТУ «ЛЭТИ». 2014. Cyculin A. K., Adamov D.Yu., Mancvetov A. A., Zubakin I. A. Tverdotel'nye telekamery: nakoplenie kachestva informacii. SPb.: - SPbCEHTU «LEHTI». 2014. 